\title{
A Comprehensive Outlook of Mining Industry in Jordan, Opportunities and Threats
}

\author{
Khaled Al Tarawneh \\ Civil Department, Faculty of Engineering, Isra University, Amman, Jordan \\ Email: khtarawneh62@yahoo.com
}

How to cite this paper: Al Tarawneh, K. (2016) A Comprehensive Outlook of Mining Industry in Jordan, Opportunities and Threats. Open Journal of Geology, 6, 11371148.

http://dx.doi.org/10.4236/ojg.2016.69084

Received: August 10, 2016

Accepted: September 11, 2016

Published: September 14, 2016

Copyright $\odot 2016$ by author and Scientific Research Publishing Inc. This work is licensed under the Creative Commons Attribution International License (CC BY 4.0).

http://creativecommons.org/licenses/by/4.0/

(c) (i) Open Access

\begin{abstract}
Jordan's mining sector is considered the cornerstone to the Jordanian economy. It plays a vital role in growth of many other important sectors in the economy and contributes to the Jordan's standard of living. The mining industry in Jordan is dominated by the production of phosphate, potash, building and decoration stones, glass sand and other nonmetallic resources. Recently, Jordan has been ranked as the sixth largest producer and the second largest exporter of phosphate, the fourth largest producer and the second largest exporter of potash, and has the 5th largest oilshale reserves in the world. Also, Jordan has sustainable amounts of uranium around $3 \%$ of the world resources. The main objective of this research is to focus on the present status of mining industry in Jordan with the aim to emphasis the most important industries, and its effect on the economy of Jordan in order to generate new wealth depends on its mineral endowment. A literature review has been carried out by reviewing the most published articles and the publicly available reports published by various Jordanian Institutions as well as from the private sector. The author reveals that there are many positive outlooks which are looming with an increasing domestic added value along with investing in other areas, such as feldspar, clays, travertine, gypsum, zirconium, uranium, copper and rare earth elements (REE). This requires activating the exploitation of many other untapped mineral resources in the country to achieve a progress that works for meeting the global great demands worldwide. In this context, successive governments have put effort into policies that promote and facilitate investment in the mining sector in Jordan. A comprehensive outlook of the mining sector in Jordan has been discussed in this article. The author also highlighted the opportunities and threats in this sector and more important dilemmas focused on what needs to be carried out by the Jordanian government, including important recommendations to encourage investment in this field and inspire investors in the mining industry in Jordan.
\end{abstract}




\section{Keywords}

Jordan, Mining, Exploitation, Industry, Sector, Opportunity, Threats, Investment

\section{Introduction}

Jordan occupies an area of $89,556 \mathrm{~km}^{2}$, between latitudes $29^{\circ}$ and $33^{\circ}$ north and longitudes $34^{\circ}$ and $39^{\circ}$ east (Figure 1). Jordan's central geographical location near other export markets is one of the main factors that drive the competitiveness of Jordanian production. Moreover, Jordan is moving towards allowing the private, local, Arab and international sectors to invest in the mining industry to the end of bringing about several technical advantages and financial returns for both the mining sector and the economy as whole. Since the Bronze Age, Jordan has witnessed an ancient iron and copper mining activities. At one time, mining of industrial minerals and rocks was an

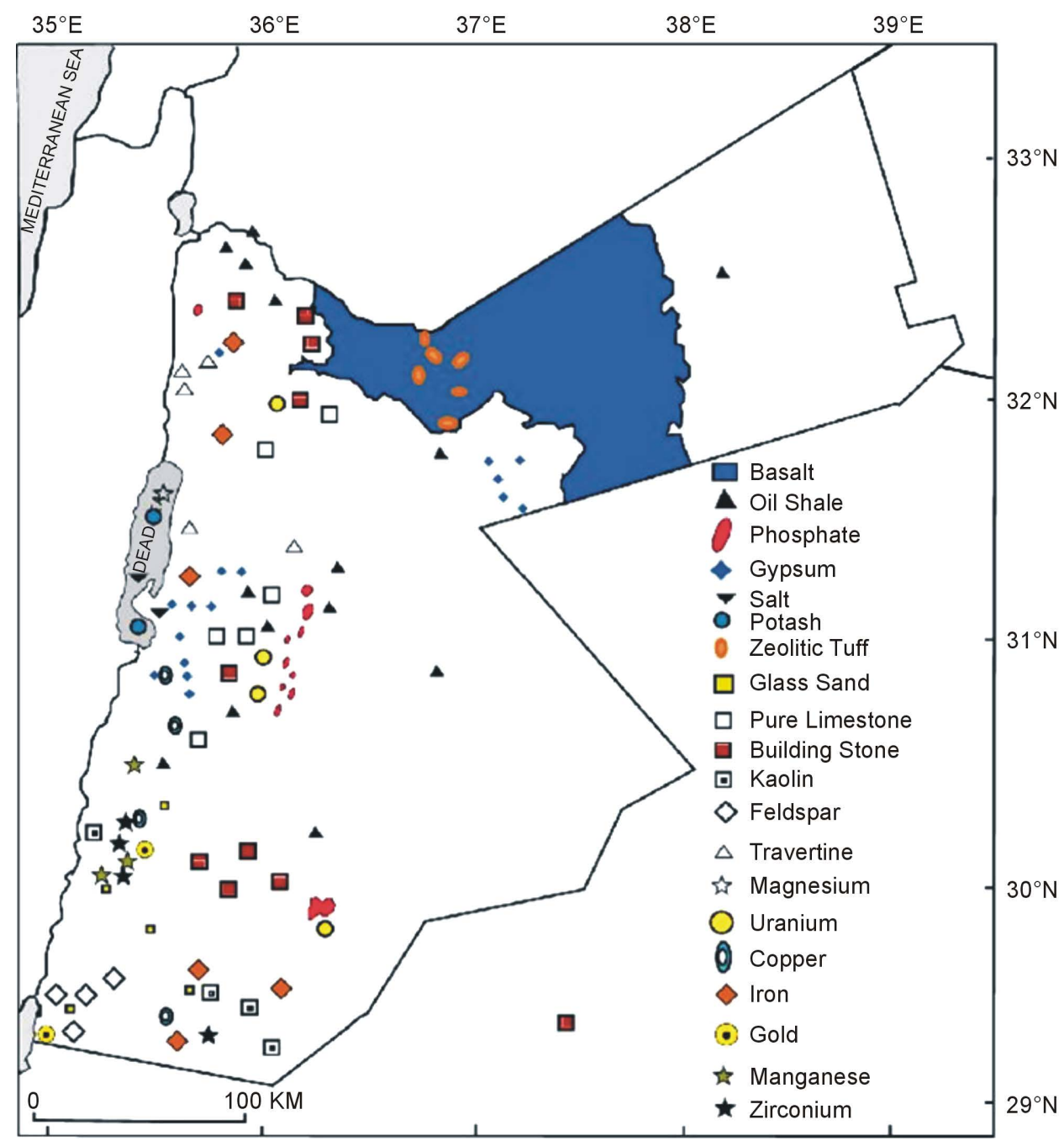

Figure 1. Distribution of metallic and non-metallic minerals in Jordan [2] [9]. 
important part of the growth of economy. In Jordan, there are more than 60 major mining facilities which employ more than 10,000 employees in the extractive industries and around 191,000 workers in manufacturing branches [1]. The mining sector contribution to Jordan's Gross National Product (GNP) in the period between 2004 and 2014 ranges from $10.5 \%$ to $15 \%$, respectively [1]-[4]. The contribution of the mining sector to GDP ratio in 2013 compared with other sectors amounted to $19.4 \%$ [1]. The report published by Jordan Department of Statistic also indicates a decrease in the index of industrial production for the month of April, 2016 by 10.1\% compared to April, 2015. This has resulted in a decrease in the production quantities of the manufacturing sector by $1.7 \%$ with a relative importance of $86.0 \%$, and production quantities of the extractive industries by $40.0 \%$. The Sustainable Budget Index (SBI), used to measure whether the user cost was reinvested or used for public consumption, has exceeded 1.0 from 2002 to 2010 which indicates that mineral revenues in Jordan have been used for public consumption rather than for investment purposes [5]. Jordan for example produces and exports phosphate and potash, because it is well endowed with high quality and low cost deposits. The wealth created from such resources will not only benefit government, mining companies, stakeholders and local communities but also phosphate and potash consumers around the world. In Jordan potash industry led the contribution among all mining products; its share was 3.9\% to the estimated GNP [6], followed by phosphate, fertilizers, cement, acids, quarries, bromine with a share of $2.9 \%, 2.8 \%, 2.2 \%, 1.6 \%$, $0.8 \%, 0.7 \%$ respectively [3] [4]. The contribution of the industrial sector to GDP for the second quarter of the year 2014 was $1.4 \%$ for extractive mining industry, and $16.2 \%$ for manufactures industry [7].

In the last decade, Jordan has been considered as one of the ten largest phosphate producing countries in the world. It is estimated that more than $60 \%$ of the area of Jordan has phosphate-bearing deposits. In Jordan, phosphate can be found at various levels in the ground ranging from zero level to $20 \mathrm{~m}$ below the surface. This makes phosphate production in Jordan quite cost effective and very competitive. There are three mines in the south of Jordan which in total produced around $8 \mathrm{Mt}$ phosphate annually of which approximately, 1.5 - $2 \mathrm{Mt}$ is used for fertilizers and acids [8]. Approved geological reserves of oil shale, building and decoration stones, clays, sand, zeolitic tuff, gypsum, diatomite, copper, manganese and other non metallic minerals and rocks have a wide distribution in Jordan [9] and as shown in Figure 1.

In spite of increasing demands for some minerals in Jordan and worldwide, the presence of various restrictions have led to slowdown in the growth of many mineral resources due to lack of interest from local and international investors in this area. In this aspect, there are some opportunities and threats that faced mining sector in Jordan. The aim of this research is to give an overview of the development of mining sector in Jordan. In particular, the author will highlight the main factors that determined the opportunities and challenges to the development of this sector in Jordan. Also to address the challenges with the aim to guide the investors and varies stakeholders to invest in this sector. Furthermore, the author, also come up with recommendations con- 
sidered by the government will inspire investors and encourage investment in the mining sector in Jordan.

\section{Methodology}

The information provided here was gathered by reviewing the most published articles and the publicly available reports published by various Jordanian Institutions as well as from the private sector. Among these institutions are Ministry of Industry and Trade, Ministry of Energy and Mineral Resources, Natural Resources Authority (NRA), Energy and Minerals Regulation Commission, Jordan Central Bank, Jordan Department of Statistic, Jordan Phosphate Mines Company (JPMC), Arab Potash Company (APC), Jordan Investment Commission, Jordan Atomic Energy Commission, and The World Bank.

\section{Mining Industry}

The mining sector in Jordan can be divided into two main sub-sectors: Nonmetallic and metallic. The nonmetallic includes minerals and rocks that have broad uses in many other sectors in the industry and plays role in the global economy of the country. The most common minerals and rocks of this subsector in Jordan consist of: phosphate, potash, light aggregate for cement industry, calcium carbonate; kaolin; gypsum; feldspar and silica; stone tablets; chalk; zeolitic tuff and pozzolana; diatomite; porcellanite and decoration materials including (slabs, marble, basalt and granite). Unlimited reserves of these materials have many applications as they are used in making of various products including fertilizers, chemicals, and cement as well as building and decoration stones. These are only examples of some the applications for these materials in this crucial subsector and no mean this is a conclusive list. The country still remains extremely underexplored in this field and a more committed scientific and systematic exploration approach is required, which will undoubtedly lead to significant new discoveries and eventually will help the economy of the country to grow and move out from recession. The recent mining history in Jordan was established by Jordan Phosphate Mines Company (JPMC) in 1935. Prospecting of minerals and exploration programs in Jordan continued for many years after the first exploitation of the phosphate rocks [10], followed by exploration of oil shale, copper, manganese, limestone, travertine, glass sand, gypsum, zeolites, dolomite, feldspar, bromine, salt and clay minerals. In the last few years Natural Resources Authority (NRA) worked intensively to attract foreign companies and to continue the exploration work and commercial exploitation for metallic minerals such as copper, manganese, gold, and radioactive elements such as uranium and zirconium.

\section{Mining Subsector in Jordan}

The mining sector in Jordan can also be divided into mineral extraction industry and mineral manufacturing industry. Mineral extraction industry covers a wide range of products including: phosphate, potash, salt, calcium carbonate, zeolites, silica and tra- 
vertine, in addition to other quarries and mines products. On the other hand the mineral manufacturing industry is composed of two branches: the chemical industry (fertilizers, chemical acids, aluminum fluoride, quick and quenched lime), and the construction materials industry (white cement, rock wool, building materials, china ceramic tiles and sanitary ware [2].

Other less mineral resources include anhydrate, barite, sulfur and rare earth elements (REE), in addition to a promising prospecting of metallic minerals such as gold, copper, manganese and iron. Radioactive elements like uranium, thorium, and zircon are present in good quantities, semi-precious stones also are abundant at many localities and scattered throughout different rock types as igneous, metamorphic and sedimentary rocks [9].

The mineral industry in Jordan has a long and a prominent history and its current and future prospects and potentials seem encouraging. The Ministry of Energy and Mineral Resources is the main regulator and instigator of most of the mining activities in the country. Its role is vital in exploration and prospecting of ores and minerals. One of the main targets of the government is to provide the interested companies with all the required information, studies and maps to help them in carrying out their exploration and extraction operations. Up to now several projects have been carried out resulted in extraction and mineral processing. More than twenty five nonmetallic minerals and four metallic minerals have been discovered. As these are major projects with large capital cost, this sector primarily relies on large investments which encouraged several firms to invest in such a promising field. The Mining Sector is the third largest industrial sector in terms of capital of industrial establishments and the fourth largest sector in terms of its relatively large and stable exports in the years 2000-2014; it also ranked first in terms of foreign investments in Jordan [3] [4]. Many positive outlooks are looming with an increasing domestic added value along with investing in other areas, such as oil shale, phosphate and uranium. This requires activating the exploitation of untapped mineral resources in the Kingdom to achieve a progress that works for meeting the global great demands.

\section{Investment in Mining Industry}

According to Jordan Chamber of Industry and Ministry of Industry and Trade [11], the quantity of companies that have share the resources into the mining business area in the year 2014 has added up to 51 offices compared with 41 companies in 2013, which demonstrate $24 \%$ development as shown in Table 1 [11] [12]. Figure 2 shows the number of establishments operating in the Mining Industry Sector in Jordan for the period from 2013 to 2014 [11] [12].

The capital of the mining investment has added up to 467.6 million Jordanian Dinars in the year 2014, compared with an about of 467.8 million Jordan Dinars in the year 2013, recording a $0.04 \%$ shortage as shown in Table 2, while Figure 3 shows the registered capitals from industry chambers through 2014 [11] [12].

The number of workers in the mining industry has come up to about 10,367 laborers 
Table 1. Number of establishments operating in the Mining Industry Sector (2013-2014) [11] [12].

\begin{tabular}{cccccccccc}
\hline \multirow{2}{*}{$\begin{array}{c}\text { Local } \\
\text { Chambers }\end{array}$} & \multicolumn{3}{c}{ Industrial Establisments } & \multicolumn{3}{c}{ Craft Establishments } & \multicolumn{3}{c}{ Total } \\
\cline { 2 - 10 } & 2013 & 2014 & Growth & 2013 & 2014 & Growth & 2013 & 2014 & Growth \\
\hline Total & 29 & 20 & $-31 \%$ & 12 & 31 & $158 \%$ & 41 & 51 & $24 \%$ \\
\hline
\end{tabular}

Table 2. Total registered capitals for establishments operating in the Mining Industry Sector in 2013-2014 (Million Dinars) [11] [12].

\begin{tabular}{ccccccccccc}
\hline \multirow{2}{*}{$\begin{array}{c}\text { Local } \\
\text { Chambers }\end{array}$} & \multicolumn{3}{c}{ Industrial Establisments } & \multicolumn{3}{c}{ Craft Establishments } & & \multicolumn{2}{c}{ Total } \\
\cline { 2 - 10 } & 2013 & 2014 & Growth & 2013 & 2014 & Growth & 2013 & 2014 & Growth \\
\hline Total & $466,857,775$ & $404,582,772$ & $-13 \%$ & 922 & 62,997 & $6733 \%$ & $467,779,775$ & $467,579,775$ & $-0.04 \%$ \\
\hline
\end{tabular}

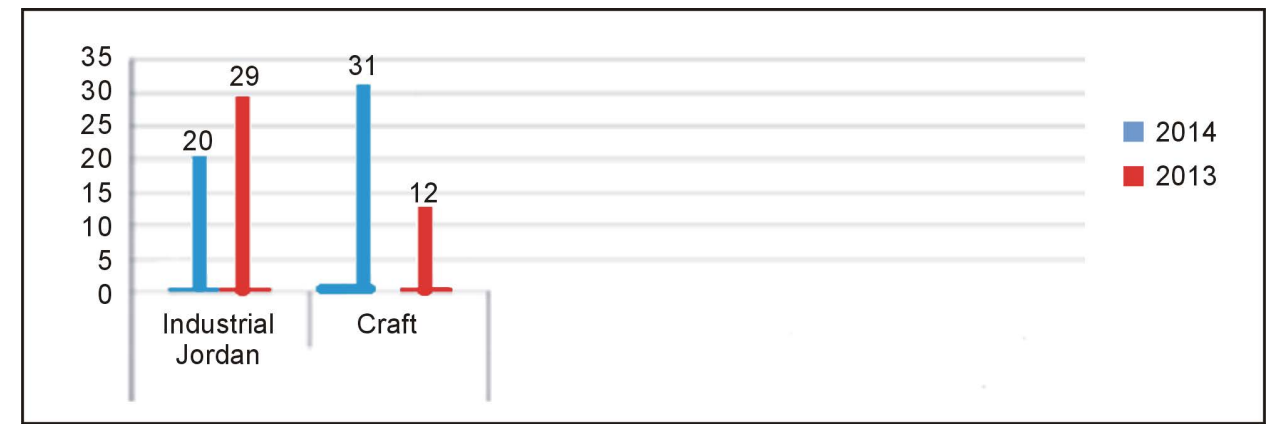

Figure 2. Number of establishments operating in the Mining Industry Sector according to Jordan (2013-2014) [11] [12].

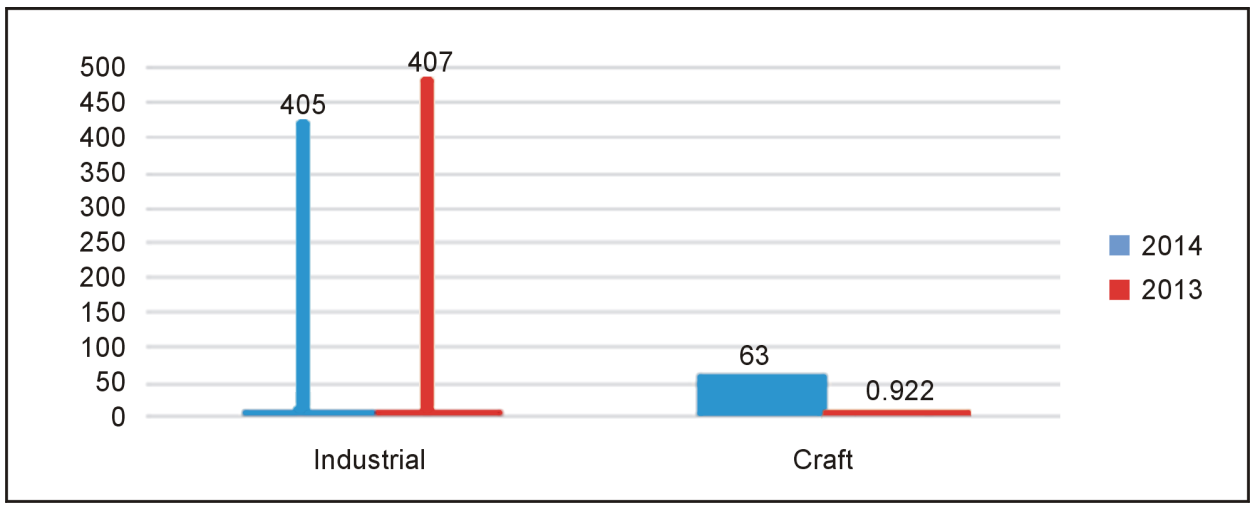

Figure 3. Total registered capitals of craft and industrial establishments in 2014 according to industry chambers (Million Dinars) [11] [12].

in the year 2014 compared with 10,524 laborers in the year 2013, recording a $1.5 \%$ reductions as shown in Table 3 and Figure 4 [7] [12].

The income of mining industry have been declined from around 653.6 million Jordanian Dinars in 2013 to around 632.5 million Jordanian Dinars in 2014, and registered $-3.2 \%$ declines as shown in Table 4 and in Figure 5 [4] [7].

It is important to notice that the biggest markets of mining industry is related to export of these industries to Arab countries as Saudi Arabia, United Arab Emirates, 
Table 3. Number of workers at establishments operating in the Mining Industry Sector in 2013-2014 [7] [12].

\begin{tabular}{|c|c|c|c|c|c|c|c|c|c|}
\hline \multirow{2}{*}{$\begin{array}{c}\text { Local } \\
\text { Chambers }\end{array}$} & \multicolumn{3}{|c|}{ Industrial Establisments } & \multicolumn{3}{|c|}{ Craft Establishments } & \multicolumn{3}{|c|}{ Total } \\
\hline & 2013 & 2014 & Growth & 2013 & 2014 & Growth & 2013 & 2014 & Growth \\
\hline
\end{tabular}

Table 4. The Mining Industry Sector total exports values (Million Jordanian Dinars) [4] [7].

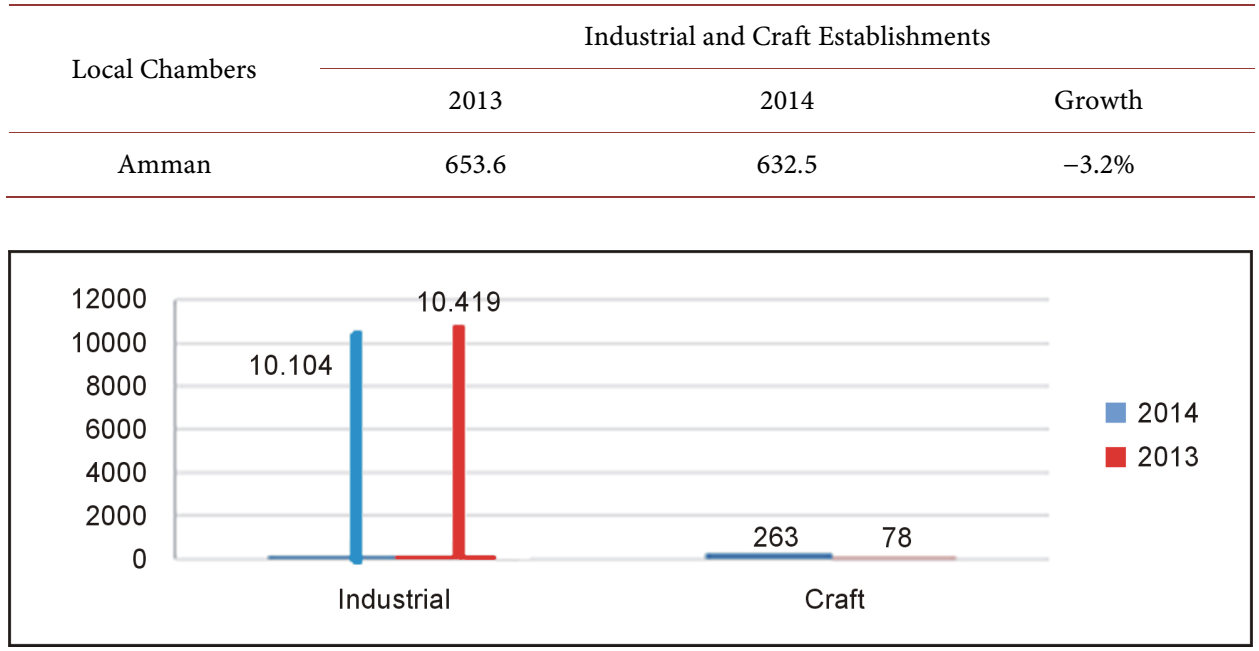

Figure 4. Show the average workers number for each registered craft and industrial establishment in chambers of industry in 2013-2014 [7].

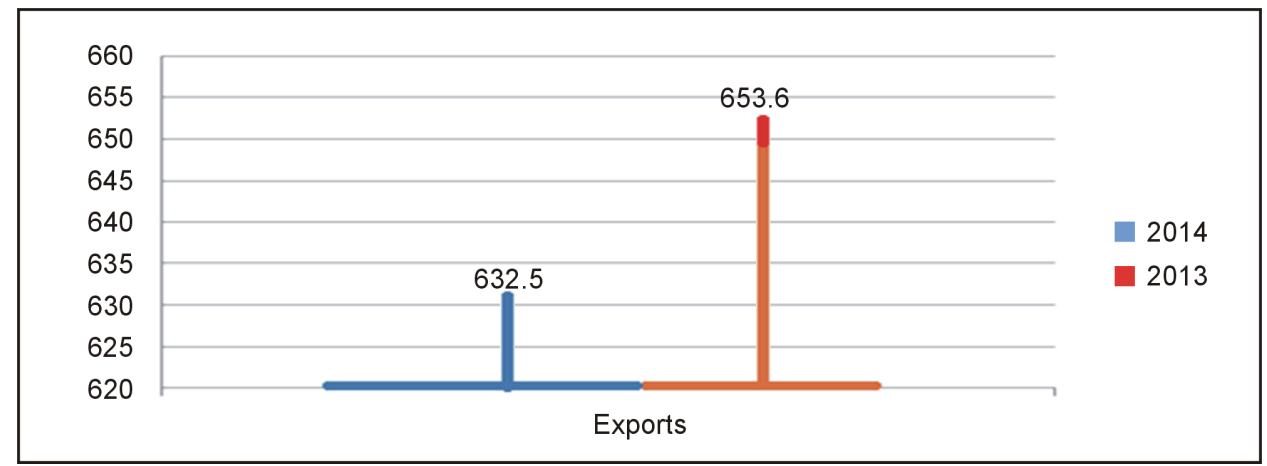

Figure 5. Industrial and craft establishments total exports in 2013-2014.

Egypt, Syria and Iraq. Export sectors additionally incorporate non-Arab countries, for example, India, Indonesia, Malaysia, Macau, Bulgaria and Singapore. The mining sector's export constitute around $12.6 \%$ of the total export of Jordan in 2014, and with contribution of 3\% to GDP. The total of export reaches up to 253.5 million JD and with $7 \%$ annually development in the last five years [4] [7]. The major players in this sector are several international extraction and production companies with mixed ownership, among them Jordan Phosphate Mining Company (JPMC); Jordan-Indian Fertilizer Co.; Canpotex (Canada); Arab Potash Co. APC (Jordan); Shell (British); La Farge (France); Enefit Co., (Ukraine); Nipon Jordan Fertilizer Co. (NJFC). 


\section{Opportunities and Threats of Mining Industry}

Jordan has benefited and well continues to benefit from mining sector through export incomes, government revenue, and also by attracting foreign investment. Income from the mining industry in Jordan over the last 60 years has been quite significant and is considered one of the main contributors to the country overall budget in addition to the significant numbers of employee that this sector is holding [5]. According to report of [4], it has been issued in 2015 over 1673 license for the export of ores and seven licenses for exploration of mineral ores and awarded six mining rights and 225 quarry license or stone crusher.

The future of mining sector in Jordan is promising and Jordan's exports of phosphate, potash, bromine, fertilizer, decoration stones, zeolites and chalk are likely to increase in the upcoming years following the completion of the export hub at Aqaba Port, which was built by APC and JPMC. The new terminal will enable the two companies to increase the volume of fertilizer, phosphate and potash exports [13]. The Government approved a project to build the first shale-oil-fired power plant. This plant will be the first of its kind in the region and it will have $500 \mathrm{MW}$ of capacity and is expected to be built by Enefit Co. of Estonia. The project is expected to begin production in 2017 [14].

In addition to the afore mentioned above, it is worth noticing that the most competitive elements considered to be of great importance for mining sector in Jordan are related to the following aspects:

1) Abundance of natural resources, particularly those that are related to industrial non-metallic minerals and rocks. Numerous minerals have been discovered in Jordan, some are with limited reserves as metallic minerals, while non-metallic ones are available with high commercial reserves. Under this field it can be mention the following competitive advantages:

- Mining processing in Jordan is mainly for non-metallic minerals of which phosphate, potash, oil shale and uranium are considered internationally recognized industries. The products from extraction of potash and mining of phosphate are increasingly being transformed into many types of chemicals and exported to many countries, whereas oil shale and uranium are still under exploitation process and foreign companies were granted the right for mining in many areas of Jordan.

- Jordan has significant mineral resources that are, or could be the basis for several downstream chemical industry clusters: phosphate, potash, silica, uranium, zeolites, clays and chalk among others. Mineral extraction industry also includes calcium carbonate (for cement manufacture), building stones and ornamental stones such as granite, basalt, marble, travertine and silica for glass industry.

- Mineral manufacturing industries include: fertilizers, chemical acids, cement, ceramic, cosmetics, rock wool, lime and silicate bricks. These industries still have strong impact on mining sector due to the demand of such industries locally and internationally.

- Several high value metals have high market potential notably: uranium, zirconium, gold, tin, copper and nickel. When both market and resource considerations are 
combined, the most likely minerals that are suitable for investment and development are uranium, manganese and copper. Minerals such as zircon are considered to have some commercial potential, while others such as tin, nickel and gold have only available in scarce amounts. Other trace elements and Rare Earth Elements are also available in many rocks in Jordan and their potential reserves still required more detailed studies.

- Oil shale is one of the most abundant resources in Jordan (over 50 billion tons of geological reserves). Several international companies in the last five years have interest in exploitation of this resource and many companies have obtained licences for exploration and extraction.

- Several mineral deposits have high levels of purity that facilitate processing to high value-added products. This includes glass sand, feldspar, uranium, zirconium, phosphates and metals.

2) Cost-competitive location for mineral extraction and manufacturing and proximity to markets especially to Asia, Europe and Gulf Cooperation Council (GCC) and improving internal transport and port facilities strengthens Jordan's cost competitiveness.

3) Strong and rapidly developing mining sector in Jordan is due to stable political situation and encouragement of successive governments for the investment in mining sector.

4) Availability of large and highly skilled engineers, technician and labours with more than 10.000 employee in the extractive industries and around 191.000 workers in the manufacturing industries.

5) Strong regulatory environment. This includes the following aspects:

- Foreigners can invest in mineral resources under special agreements and own up to $100 \%$ of mining projects. Investors receive legal title and rights for exploration, mining, and commercial exploitation for the duration of their projects. Companies are free to assign their interests and assets in projects for financing purposes; and free to market the products mined without restriction. Companies are free to conduct their commercial operations according to development plans, subject to normal environmental and safety regulations.

- Environmental regulations are comparable to international best practice and environmental impact assessment is well recommended for mining process.

- Higher education that met the requirements of development of mining sector delivered by highly skilled experts, graduate engineers, technicians and labours.

Based on the mentioned competitive advantages of the mining sector in Jordan, it can be concluded that the most opportunities of this sector can be considered as following:

- Many Jordanian companies seek joint ventures for technology transfer due to the demand of development in the mining sector locally and worldwide. This is due to expansion of demand for fertilizers, building, decoration stones and raw materials that should faced the growth of population that increased dramatically in last four 
years due to instability in the neighbour countries and migration.

- Further processing and manufacturing of already established mineral extraction products as phosphate, potash, glass sand, basalt, feldspar, copper, magnesium, gold, zirconium and uranium, in addition to processes to make high value metals and Rare Earth Elements (REE) from different types of rocks.

- Mineral exploration projects with huge reserves-oil shale, phosphate, limestone, dolomite, feldspar, sand, gypsum, clays and zeolites encourage many companies to take share in these projects.

- Increasing demands for interdisciplinary study of mining engineering, geology and earth sciences that support the development of the mining sector in Jordan by highly skilled experts, engineers and technicians.

However, a serious threats which can have negative effect on the future development of mining sector in Jordan. These threats can be categorized into three main groups:

First group threats that belong to laws and regulations in the mining sector; second group, threats that are related to environmental issues; and third group, threats that are due to political stability of the country and in region. Regarding the threats related to the laws and regulations of the mining sector, they can be managed by adjusting the law and regulations in a way to encourage investment in the mining industry sector. The Mining Regulation (No. 131 of 1966) contains prescribed standards for mining, including employment conditions; Civil Code (No. 43 1976) contains provisions relevant to ownership of minerals; Environmental Protection Law (No. 1 2003): governs Environmental Impact Assessments for mining activities. Natural Resources Affairs Law (No. 12 1968) and amendments for regulating Natural Resources Affairs then developed of the Natural Resources Authority (NRA), which is the governmental body responsible for issuing licenses, conducting geological and economic studies for mineral resources, and supervising technical issues for mining projects. Licenses are based on a concession system. The NRA was dissolved in 2014 and all laws and regulation governing the mining sector became the responsibility of the Energy and Minerals Regulation Commission. However, the mining law in Jordan has not been modified, and it has not been amended until this moment, with some exceptions of limited regulations that have been modified over the last 10 years. These changes have not met the requirements of modernization and privatization, and the desire of investors in this sector. There are environmental issues that are affects the investment of some metals in Jordan like copper due to its location in areas of natural reservation in the southern part of the country. However, there is an opportunity for investment by foreign companies that will take into consideration the environmental impact assessment during the future mining of copper and associated metals. Regarding the political stability, this issue is not limited only to Jordan, but the whole region and is considered one of the reasons that some companies take it into consideration when they decide to invest. However, Jordan in compare with most of the surrounding countries and the region as a whole is considered relatively politically stable and provide safe environment for investors.

Other threats that have effect on the mining sector can be considered in the shortages 
of energy resources in Jordan and instability of its prices, in addition to the financial and technical risks. Thus, providing understanding of the technical risk associated with the mineral reserve estimate is essential. This methodology of ranking and analysis should be well documented [5]. Like other assets, one might intuitively expect that mineral wealth should help economic development of countries and should assist the economic fortunes of a nation or a region by improving services, building infrastructure, more employment in local communities and by raising demand for goods and services which would ultimately enhance political stability and boost economic growth [15].

Nonrenewable resources like minerals well eventually are be depleted, and the employment and income generated by this activity will come to an end. Therefore, it is crucial that surplus from such minerals industry be invested in other kinds of economic activity, which can replace the employment and income from mineral-based industries once they are exhausted. In this way exploitation of minerals can be economically sustainable because it creates a permanent source of income [5].

\section{Conclusion}

Jordan's mining sector is considered the cornerstone to the Jordanian economy. Many positive outlooks are looming with an increasing domestic added value along with investing in other areas, such as oil shale, phosphate and uranium. There are many competitive elements of mining industry in Jordan which are identified with numerous viewpoints, for example, abundance of natural resources, cost-competitive location for mineral extraction and manufacturing and proximity to markets, large and highly skilled labors, infrastructure and solid administrative environment and political stability. These aspects will maximize the opportunities of this sector, like expansion for demand of building and decoration stones, mineral extraction products, glass manufacture from silica, mining and processing of copper, gold, zirconium and uranium; phosphate, limestone, dolomite, feldspar, clays, potash; oil shale extraction for direct combustion power plants; basalt extraction for fibber; zeolite mining for many application as fertilizers. In spite of that, it can be noticed that there are serious threats to future development of mining sector. These threats are related to restrictions and requirements of laws and regulations of the mining sector, in addition to environmental issues and unstable political situation in the region. Each one has its negative effect that should be taken into consideration by the government and private sectors for future development of mining sector in Jordan. To minimize the effects of these threats, the government of Jordan should update the laws and regulations that stimulate investment in this sector and reconsider many of these instructions with the aim to achieve sustainability of investment in the mining sector and improve Gross National Product of Jordan.

\section{Acknowledgements}

The author would like to thank all Jordanian institutions that support this research by 
providing data, particularly Ministry of Industry and Trade, Arab Potash Company, Central Bank of Jordan, Jordan Phosphate Mines Company, Jordan Atomic Energy, Jordan Investment Commission, Ministry of Energy and Mineral Resources, Jordan Chamber of Industry and Energy and Minerals Regulation Commission.

\section{References}

[1] Jordan Department of Statistic (2014) Annual Reports 2010-2014. http://cn.knoema.com/atlas/sources/Jordan-Department-of-Statistics?topic=Jordan

[2] Natural Resources Authority (2000-2013) Mining Sector Performance during 2011 Compared with the Last Four Years. Natural Resources Authority, Amman, Jordan, 39. http://www.philadelphia.edu.jo/newlibrary/pdf/file33cf0f62b2314d998ec74abc0f825bf4.pdf

[3] Central Bank of Jordan (2014) Annual Reports (2010-2013). Central Bank of Jordan, 82 p. http://www.cbj.gov.jo/

[4] Energy and Minerals Regulation Commission (2014) Annual Report of Energy and Mining Sector. www.emrc.gov.jo

[5] Alrawashdeh, R. and Al Tarawneh, K. (2014) Sustainability of Phosphate and Potash Reserves in Jordan. International Journal of Sustainable Economy, 6, 45-63. http://dx.doi.org/10.1504/IJSE.2014.058513

[6] Arab Potash Company (2013) Fifty-Sixth Annual Report 2012: Arab Potash Co. 80 p. http://www.arabpotash.com/

[7] Ministry of Industry and Trade (2000-2014) Annual Reports 2004-2013. http://www.mit.gov.jo/Pages/viewpage.aspx?pageID=181

[8] Jordan Phosphate Mines Company (2013) Annual Reports 2004-2012. Amman, Jordan. http://www.mit.gov.jo/Pages/viewpage.aspx?pageID=181

[9] Alnawafleh, H., Al Tarawneh, K. and Alrawashdeh, R. (2013) Geologic and Economic Potentials of Minerals and Industrial Rocks in Jordan. Natural Science, 5, 756-769. http://dx.doi.org/10.4236/ns.2013.56092

[10] Al Tarawneh, K. (2008) Jordanian Phosphate Mining History. Fifth International Conference of Beneficiation of Phosphates, Rio de Janeiro, Brazil, 45.

[11] Ramadna, A. (2012) Mining Sector in Jordan, Current Situation and Investment Opportunities. Report of Ministry of Industry and Trade, Jordan.

[12] (2014) Jordan Chamber of Industry. Internal Report. www.jci.org.jo

[13] Mowafa, T. (2014) The Mineral Industry of Jordan. By Minerals Yearbook. U.S. Department of the Interior U.S. Geological Survey in JORDAN [ADVANCE RELEASE] 2012 Minerals Yearbook.

[14] Roscoe, A. (2013) Jordan Approves Region's First Shale Oil-Fired Power Plant: MEED Media FZ L.L.C., 17 June.

http://www.meed.com/sectors/power/power-generation/jordan-approves-regions-first-shal e-oil-fired-power-plant/3182478.article

[15] Alrawashdeh, R., Al-Titi, A., Al Tarawneh, K. and Awawdeh, M. (2013) Socio-Economic Impact of Mining on the Jordanian Local Communities. Seventh International Jordanian Mining Conference, Jordan Engineers Association, Book of Abstract, 56. 
Submit or recommend next manuscript to SCIRP and we will provide best service for you:

Accepting pre-submission inquiries through Email, Facebook, LinkedIn, Twitter, etc. A wide selection of journals (inclusive of 9 subjects, more than 200 journals)

Providing 24-hour high-quality service

User-friendly online submission system

Fair and swift peer-review system

Efficient typesetting and proofreading procedure

Display of the result of downloads and visits, as well as the number of cited articles

Maximum dissemination of your research work

Submit your manuscript at: http://papersubmission.scirp.org/ 